\title{
The performance of the Norwegian carbon dioxide, capture and storage innovation system
}

\author{
Klaas van Alphen ${ }^{\mathrm{a}, *}$, Jochem van Ruijven ${ }^{\mathrm{a}}$, Sjur Kasa ${ }^{\mathrm{b}}$, Marko Hekkert ${ }^{\mathrm{a}}$, Wim Turkenburg ${ }^{\mathrm{c}}$ \\ a Department of Innovation Studies, Copernicus Institute for Sustainable Development and Innovation, Utrecht University, P.O. Box 80115, 3508 TC Utrecht, The Netherlands \\ b Center for International Climate and Environmental Research Oslo (CICERO), University of Oslo, P.O. Box 1129, 0318 Blindern, Oslo, Norway \\ ${ }^{\mathrm{c}}$ Department of Science, Technology and Society, Copernicus Institute for Sustainable Development and Innovation, Utrecht University, Heidelberglaan 2, \\ 3584 CS Utrecht, The Netherlands
}

\section{A R T I C L E I N F O}

\section{Article history:}

Received 8 May 2008

Accepted 21 July 2008

Available online 18 September 2008

Keywords:

CCS RD\&D in Norway

Innovation system functions

Energy transition

\begin{abstract}
A B S T R A C T
In order to take up Norway's twin challenge of reducing $\mathrm{CO}_{2}$ emissions, while meeting its growing energy demand with domestic resources, the deployment of carbon capture and storage (CCS) plays an important role in Norwegian energy policies. This study uses the Functions of Innovation Systems approach to identify key policy issues that need to be addressed in order to prolong Norway's international leadership position in the development of CCS. The analysis shows that Norway has been successful in building an innovation system around CCS technology. The key determinants for this achievement are pinpointed in this article. However, the evolution of the innovation system seems to have entered a critical phase that is decisive for a further thriving development of CCS in Norway. The results provide a clear understanding of the current impediments in the CCS innovation system and stress the need to direct policy initiatives at the identified weak system functions-i.e. entrepreneurial activity and market formation-to improve the performance of the system. We discuss how policymakers can use these insights to develop a coherent set of policy instruments that would foster the deployment of CCS concepts related to power production and enhanced oil recovery in Norway.

(c) 2008 Elsevier Ltd. All rights reserved.
\end{abstract}

\section{Introduction}

Norway is the largest petroleum exporting country of Europe, as only a small fraction of the produced 233 Mtoe is used domestically (IEA, 2005). In fact, half of the national primary energy demand of approximately 21 Mtoe is met by $\mathrm{CO}_{2}$ emissionfree hydropower, providing 99\% of the generated electricity in Norway (Kjærland, 2007). This makes Norway's $\mathrm{CO}_{2}$ emissions, in relation to its total energy use and GDP, relatively low compared with other OECD countries. Therefore, Norway is allowed in the Kyoto Protocol to increase its greenhouse gas (GHG) emissions with 1\% in the period 2008-2012 compared with the level of 1990 (NME, 2005). However, Statistics Norway (2007) showed that Norway's GHG emissions already increased with $8.5 \%$. This is mainly caused by a 78\% emission growth of the oil and gas industry since 1990; this industry is responsible for more than a quarter of all GHG emissions in Norway.

The Norwegian GHG emissions may rise even further, if the considered diversification strategy towards gas-fired power plants

\footnotetext{
* Corresponding author. Tel.: +31302537484; fax: +31302532746

E-mail address: k.vanalphen@geo.uu.nl (K. van Alphen).
}

is pursued to meet the growing electricity demand of $1-1.5 \%$ per year (Trømborg et al., 2007). Even though the deployment of gas power has been on the political agenda for over a decade, its implementation has continuously been delayed due to environmental concerns related to $\mathrm{CO}_{2}$ emissions (Godoe and Nygaard, 2006). However, the increasing viability of carbon capture and storage (CCS) provides a possible solution to Norway's twin challenge of reducing GHG emissions, while meeting a growing energy demand with domestic resources. ${ }^{1}$

CCS technology comprises the separation of $\mathrm{CO}_{2}$ from industrial and energy-related sources, transport to a storage location (e.g. saline aquifers and depleted hydrocarbon fields), and longterm isolation from the atmosphere (IPCC, 2005). The Norwegian industry already gained valuable experience in this area from its $\mathrm{CO}_{2}$ storage operations at the Sleipner West gas field, where $1 \mathrm{MtCO}_{2}$ is injected into a sub-surface reservoir each year, since 1996 (Torp and Gale, 2004). Meanwhile, new CCS activitiesparticularly those concerning natural gas-based power production-have increased significantly over the past several years in Norway (OED, 2007). Most of the current CCS programs

\footnotetext{
${ }^{1}$ Environmental concerns have halted both the development of new hydropower and nuclear energy.
} 
by companies and research institutions are established in cooperation with the Norwegian authorities (Gassnova, 2006), as the deployment of CCS plays an important role in the Norwegian climate and energy policy (IEA, 2005; Torvanger et al., 2007).

The emergence of new technological trajectories, like CCS, is a complex and uncertain process, which is difficult to steer. Thus, for governmental bodies that intend to promote and shape the development of CCS technology, this is a phenomenal challenge. The question of how a process of socio-technical change, also labelled as a technological transition, can be understood and influenced is receiving increasing attention in scientific literature (see e.g. Geels, 2002; Kemp et al., 2007; Smith et al., 2005). One of the frameworks that has been successfully applied to several emergent trajectories of energy technologies is that of technological innovation systems (TIS) (see e.g. Foxon et al., 2005; Jacobsson and Bergek, 2004; Jacobsson and Johnson, 2000; Negro et al., 2007). This framework is rooted in the field of innovation studies and is used to analyse the "network of actors interacting in a technological area under a particular institutional infrastructure and involved in the generation, diffusion and utilisation of technology" (Carlsson and Stankiewicz, 1991).

The central link between a TIS and socio-technical change is that emerging technologies are developed and applied within the context of a specific TIS. The maturation of technology and the growth of a TIS is a typical example of co-evolution; they mutually influence each other. When the technology matures, the TIS also grows due to an increasing knowledge base, new entrants, growing networks in terms of size and density, and due to specific institutional arrangements that come into place. On the other hand, when a TIS grows the rate of technological progress generally increases, which in turn enlarges the chances of success for the technology (Hekkert and Negro, 2008).

Over the past years, progress is made in determining functions that contribute to the growth and performance of an emerging TIS (see Edquist, 2004; Hekkert et al., 2007b; Jacobsson and Bergek, 2004; Johnson, 2001). These system functions are decisive processes, or key activities, that foster the shaping and development of a technology (Edquist, 2001). In earlier empirical work these functions have been used effectively to deliver explanations for the success or failure of technological trajectories of sustainable energy technologies in various countries (see e.g. Alkemade et al., 2007; Hekkert et al., 2007a; Jacobsson et al., 2002; Jacobsson, 2008; Negro et al., 2008; van Alphen et al., 2008).

This study applies the framework of innovation system functions to describe the evolution of the Norwegian CCS innovation system and evaluate its current performance. We aim to provide insights into the relations between the historical dynamics of the system and the system's current performance. Furthermore, we will demonstrate how these insights can be useful to policy makers that wish to enhance the development and deployment of CCS. ${ }^{2}$

The article is structured as follows: first an overview is given of how innovation system functions may optimally contribute to the development of emerging energy technologies in Section 2. Based on this, an analytical framework is constructed, which is applied in the subsequent sections to analyse the historical dynamics and the current performance of the Norwegian CCS innovation system. Finally, the results are used to advice on how the performance this TIS can be improved and malfunctions can be remedied.

\section{Theoretical framework: innovation system functions}

A number of different innovation system concepts have been put forward in the literature, including national systems of innovation (Freeman, 1987; Lundvall, 1992; Nelson, 1992), regional innovation systems (Asheim and Isaksen, 1997; Doloreux and Parto, 2004), sectoral systems of innovation and production (Malerba, 2002) and technological systems (Carlsson and Stankiewicz, 1991). In this paper, we apply this TIS framework, i.e. socio-technical systems focused on the development, diffusion and use of a particular technology (in this case CCS technology).

A TIS typically crosses geographic-as well as sectoral boundaries (Hekkert et al., 2007b). For example, the capture of $\mathrm{CO}_{2}$ in the CCS process is mainly embedded in the power sector, while $\mathrm{CO}_{2}$-storage is partly the domain of the gas-and oil industry. Although, a TIS is often international in nature, system delineation usually encompasses a further specification in spatial terms, depending on the purpose of the analysis (Markard and Truffer, 2008). Therefore, we define ${ }^{3}$ the Norwegian CCS innovation system as: 'a network of actors interacting under a particular institutional infrastructure and involved in the development, diffusion, and utilisation of CCS technology in Norway.'

According to this definition a TIS can be described by its three main components: actors, institutions and their relationships (networks). Actors or organisations are the operating parts of a system and can be of a variety of types, such as individuals, firms, banks, universities, research institutes, and public policy agencies. Institutions can be in the form of legislative artefacts such as laws, policy targets and social norms, which in turn regulate (network) interactions between actors.

In this paper, we present a framework outlining seven key processes-here labelled 'functions'-, which have a direct impact on the development, diffusion and use of new technologies, i.e. the overall function of the TIS as defined above. These functionse.g. the formation of markets and the mobilisation of resourcesare the emergent properties of the interplay between actors and institutions. This framework has been applied effectively to describe and explain the (historical) dynamics of innovation systems at different levels of aggregation (for an overview, see Hekkert and Negro, 2008). Furthermore, the fulfilment of these functions can be assessed in order to derive policy recommendations for supporting the development of a specific technology (Bergek et al., 2008).

A series of empirical as well as conceptual articles have proposed different sets of sub-functions for the analysis of innovation systems (for an overview, see Bergek et al., 2008; Hekkert et al., 2007b). The seven functions that are applied in this study to describe the dynamics of Norwegian CCS innovation system, assess its performance and arrive at policy recommendations, includes the functions on which there is quite large agreement between different functions approaches (Hekkert and Negro, 2008).

Function 1. Entrepreneurial activity: The existence of entrepreneurs in innovation systems is of prime importance. The role of the entrepreneur is to turn the potential of new knowledge into concrete actions to take advantage of business opportunities and stimulate learning by doing. Entrepreneurs can be new entrants that have the vision of business opportunities in new markets, or incumbent companies who diversify their business strategy to take advantage of new developments. Entrepreneurs are very

\footnotetext{
${ }^{2}$ Note that the insights related to the performance of the system are also interesting for other organization-e.g. industrial parties and NGOs-that aim to strategically influence the development of CCS (Bergek et al., 2006).
}

\footnotetext{
${ }^{3}$ This definition is based on the description of a technology-specific innovation system by Carlsson and Stankiewicz (1991), which is presented in Section 1.
} 
important in overcoming the uncertainties that are present in the early stage of development of a new technology.

Function 2. Knowledge creation: Research and development (R\&D) is a prerequisite for innovation. Mechanisms of learning are at the heart of any innovation process. For instance, according to Lundvall (1992): "the most fundamental resource in the modern economy is knowledge and, accordingly, the most important process is learning". This function encompasses learning by searching and is associated with R\&D and patenting activities that create a variety in the knowledge base.

Function 3. Knowledge diffusion through networks: The diffusion of knowledge through networks of actors contributes to learning by interacting and facilitates the exchange of information, e.g. by workshops, conferences and research collaborations This is important in a strict R\&D setting, but especially in a heterogeneous context where R\&D meets government, competitors and market. When the development of knowledge (Function 2) is diffused throughout the network, learning at system level takes place, which enhances technology development and diffusion.

Function 4. Guidance: This system function represents the selection process necessary for the convergence in technology development. Therefore, the activities within the innovation system that can positively affect the visibility and clarity of specific wants among technology users fall under this system function. Guidance can take the institutional form of policy targets, but is often realised through expectations regarding the technology as expressed by various actors. This grants a certain degree of legitimacy to the development of the technologies and stimulates the mobilisation of resources for this development.

Function 5. Market formation: Emerging (sustainable energy) technologies often have difficulty with competing in existing markets. Therefore it is important to create protected spaces for new technologies. One possibility is the formation of niche markets for specific applications of the technology. This can be done by governments but also by other actors in the innovation system. Another possibility is to create a temporary competitive advantage by favourable tax regimes, minimal consumption quotas, or other activities in the sphere of public policy.

Function 6. Resources mobilisation: The allocation of resources, both human and financial, is a necessary and basic input to all the activities in the innovation process. Both R\&D and the construction of production facilities require financial resources, either from internal or external funds, e.g., government subsidies and venture capital. In terms of human capital, one could think of well-educated and knowledgeable professionals in all parts of the innovation system.

Function 7. Creation of legitimacy/counteract resistance to change: The new technology and its proponents need to be considered as desirable by the other actors in the system to acquire political strength. Parties with vested interests often oppose to the new technology. This function describes activities that influence the acceptance of technology with respect to policy and society, as the new technology should comply with legislation and relevant institutions. Advocacy coalitions are of great importance in this process, as they can put a new technology on the (political) agenda, lobby for resources or favourable tax regimes and by doing so create legitimacy for the new technological trajectory.

It is possible that the fulfilment of a certain function has effects on other functions (Hekkert et al., 2007b). For instance, a certain amount of knowledge creation is necessary to build expectations for the new technology, which may lead to an increasing availability of financial resources (Negro et al., 2008). This implies that function fulfilment can lead to positive (virtuous) cycles of processes that strengthen each other and lead to the growth of the TIS. However, if particular system functions are inadequately addressed by the components of the system, a negative (vicious) cycle may be set off (Bergek et al., 2006). Therefore, positive 'system dynamics' can be considered as a prerequisite for the successful development and deployment of emerging technologies, like CCS (Suurs and Hekkert, 2008). The analytical framework that is outlined below elucidates this.

\subsection{Framework of analysis: dynamics, performance and policy intervention}

The practical relevance of this analytical framework is based on the assumption that policy interventions directed at stimulating sustainable changes in the energy system should focus on improving innovation system functions that operate weakly in order to increase the chances of positive system dynamics. To specify these policy interventions it is necessary to analyse the relationship between the historical dynamics and the current performance of the innovation system. The relationships between innovation system dynamics, performance and policy, are further clarified by the three different analytical parts that are discerned in this study.

Part 1: The first part consists of mapping the historical dynamics of the innovation system in terms of (interactions between) functions. This includes the identification of the structural components that compose the TIS (actors, institutions and networks) and their contribution to the fulfilment of the seven innovation system functions through time. ${ }^{4}$ The data for this sub-analysis is collected by reviewing scientific as well as 'grey literature' (newspaper articles, professional journals and policy documents), and by interviewing the main actors involved in the development of CCS in Norway. In total, 20 interviews have been conducted. With the selection of interviewees a balanced representation of the different actor groups in the innovation system was pursued. Thereby a distinction is made between the following groups of actors: technology-developers, industry, research organisations, governmental parties and environmental NGOs. All of the interviewees have been involved in the development of CCS in Norway for a longer period of time, but are not necessarily proponents of the technology.

This part of the analysis results in a narrative that describes the appearance and evolution of the Norwegian CCS innovation system. It explains the growth of the system in terms of changes in the fulfilment of innovation system functions by its components. This narrative is used to point out how system functions reinforce or antagonise each other through time; thereby creating insight in the historical dynamics (growth) of the TIS.

Part 2: The second part of the analysis assesses the performance of the innovation system, as insights in the dynamics of the TIS do not tell us directly whether the innovation system is well functioning or not. In order to further assess the system's performance-i.e. not how, but how well the system is functioning - the relative 'goodness' of its dynamics needs to be evaluated (Bergek et al., 2008). Since by definition diffusion is low for emerging technologies, it is problematic to test whether a good fulfilment of these functions of innovation systems indeed leads to successful diffusion. Therefore, we propose several indicators or 'evaluation questions' that provide insight in the performance of the functions separately (see Table 1). In order to determine possible improvements in function fulfilment we assessed the performance of functions for different time periods and compared these. To specify the current performance of the TIS even further, the main actors in the system are asked to reflect upon the historical, as well as ongoing activities in the TIS and rate

\footnotetext{
${ }^{4}$ Note that these can also be international actors, or institutions that influence the development of CCS in Norway.
} 


\section{Table 1}

Indicative questions that reflect the extent to which each function in the innovation system is fulfilled by the system components (see also Bergek et al. 2008; Hekkert et al., 2007b)

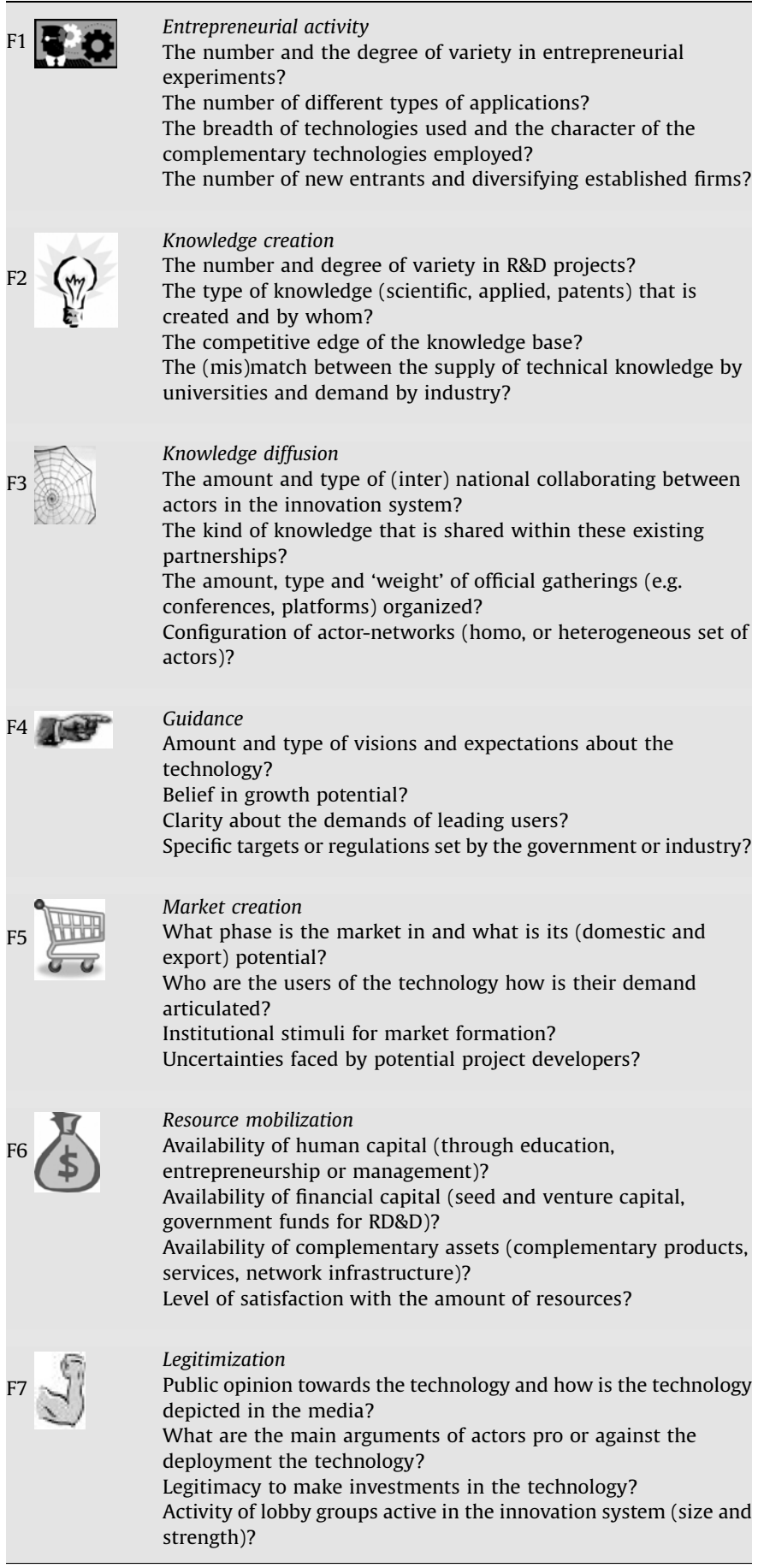

their level of satisfaction with the fulfilment of a particular system function. In this way the identification of functions that either induce (drive) or block positive system dynamics is verified by critical evaluations from experts who take part in shaping the technological trajectory for CCS.

Part 3: The third and last part of this analytical framework consists of the identification of key policy issues. Based on the current performance of the system, in relation to what is reasonable to expect taking the historical development of the
TIS into account and according to the judgment of key actors in the system, it is possible to specify policy issues in terms of how the innovation system functions should develop in order to reach a higher performance. Furthermore, the respondents not only evaluated the current functioning of the TIS, but they also gave their view on what should be done to improve functions that are impeding positive system dynamics. This provides the basis for advice on policy strategies to enhance the development of deployment of CCS in Norway.

\section{Dynamics of the Norwegian CCS innovation system}

This section discusses the dynamics of the Norwegian CCS innovation system by reconstructing its appearance and evolution (growth) over the past two decades. The narrative is chronologically organised into two periods. Each period covers two episodes characterised by a specific interaction pattern between functions. These dynamic patterns are discussed briefly at the end of every episode and depicted schematically in Figs. 2, 3, 5 and 6. This implies, that the end of each episode is chosen on the basis of change in activities (function fulfillment), consequently the four episodes are not equal in length. All the major events that have influenced the development of the Norwegian CCS innovation system will be discussed below and refer to the various system functions as F1, F2, F3, etc., following Table 1 .

\subsection{Period 1988-1999}

The concept of CCS in Norway is originated between 1986 and 1988, when researchers from the Norwegian research institution SINTEF suggested the capture and storage of $\mathrm{CO}_{2}$ in a study conducted for Norway's largest oil company Statoil. During that period, the report 'our common future' of the Brundtland Commission about the growing tension between economic growth and ecological deterioration was published (Burton, 1987). After chairing the commission, Brundtland was re-elected as Norway's prime minister in 1990 and 1 year later she introduced a carbon tax for different fuels and sectors. This marks the start of an era wherein Norway fulfils a pioneering role in the field of CCS.

\subsubsection{Episode 1: pioneering activities}

The introduction of a carbon tax for offshore petroleum activities (approximately $€ 40$ per emitted tonne of $\mathrm{CO}_{2}$ ) triggered Statoil to investigate options for cost-effective $\mathrm{CO}_{2}$ handling at their offshore Sleipner West gas field (F2), including the underground storage of $\mathrm{CO}_{2}$ in geological formations (Karstad, 1992). This natural gas field contains around $9 \% \mathrm{CO}_{2}$ that needs to be removed to use the gas for commercial purposes. If vented, the $\mathrm{CO}_{2}$ would not only have increased Norway's $\mathrm{CO}_{2}$ emissions with $3 \%$, but also imposed a financial burden on the project due to the carbon tax (Kongsjorden et al., 1998).

In 1992, Statoil opted to inject the $\mathrm{CO}_{2}$ in the Utsira formation, a large aquifer southwest of Norway with a capacity of probably more than hundred times the European annual $\mathrm{CO}_{2}$ emissions. ${ }^{5}$ In order to realise its plans, Statoil made available a research budget of $€ 1.25-2.5$ million per year $(F 6)$ to simulate the distribution of $\mathrm{CO}_{2}$ in the Utsira formation (Korbol and Kaddour, 1995). Hereby, Statoil cooperated with SINTEF and the Trondheim-based technical university NTNU (F3). Additionally, Statoil initiated

\footnotetext{
${ }^{5}$ SINTEF and Statoil participated in a research project funded by the EU program Joule II from 1993 to 1996 (F2), which assessed the storage capacity in the North Sea, including the Utsira formation (Holloway et al., 1996).
} 
Brundtland report: 1992-‘96: (Inter)national environmetal concerns research collaborations

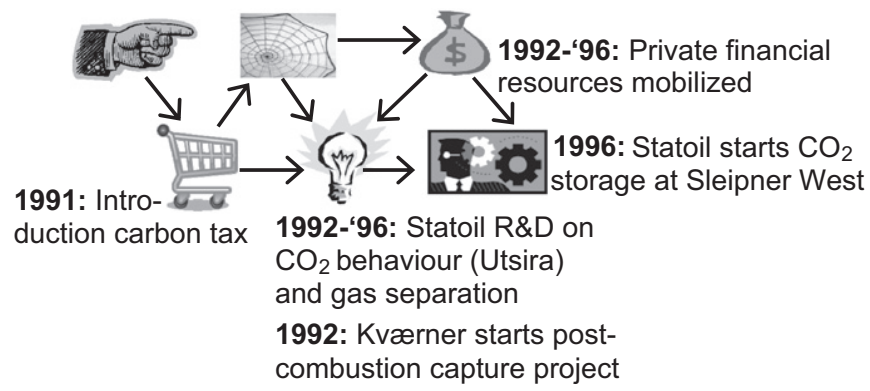

Fig. 1. Function interactions episode I: 1991-1996.

commercial R\&D efforts (F2) to apply a $\mathrm{CO}_{2}$ separation unit offshore (Karstad, 2002b). In this R\&D process they aligned with Kværner; one of Norway's largest technology vendors (F3). Following these R\&D programs (F2), Statoil invested $€ 94$ million in the separation unit (F6) and started operations in 1996 (F1); sequestering $1 \mathrm{MtCO}_{2}$ each year (Berger et al., 2003).

In the same year that Statoil announced its plans to sequester $\mathrm{CO}_{2}$ in the Utsira formation (1992), the company started initial discussions with Kværner to find a cost-effective solution for the $\mathrm{CO}_{2}$ emissions from offshore gas turbines. These emissions represent more than $80 \%$ of the $\mathrm{CO}_{2}$ discharge by Norway's oil and gas industry and are therefore subjected to high carbon taxes (Falk-Pedersen and Dannstrom, 1997). Due to this carbon tax, Kværner knew the commercial value of $\mathrm{CO}_{2}$ capture technology and started R\&D of a post-combustion technique based on amine absorption using membrane contactors (F2) (Falk-Pedersen et al., 1995). This R\&D was partly done in cooperation, but also in competition with similar developments abroad. ${ }^{6}$ During the project Kværner established a partnership with Gore Industries and involved six other oil international companies besides Statoil.

During Kværner's R\&D efforts, the Norwegian Oil Industry Association criticised $\mathrm{CO}_{2}$ capture at offshore gas turbines by pointing at the energy losses in the capture process and unfeasibly high costs (Tjernshaugen, 2007). Furthermore, some environmental groups, including Greenpeace, placed a critical note by the storage of $\mathrm{CO}_{2}$ in the Utsira formation (F7), as they claimed that Statoil was in violation with the London Convention when 'dumping' $\mathrm{CO}_{2}$ under the seabed (Johnston, 1999).

Fig. 1 depicts the relation between the introduction of the carbon tax (F5) and the applied R\&D that has led to the world's first offshore $\mathrm{CO}_{2}$ capture plant, together with a still unique $\mathrm{CO}_{2}$ storage project (F1). Furthermore, it shows the research collaborations that were set up to share knowledge (F3) and to mobilise financial resources (F6) into this and other (typically expensive) CCS projects. This increased attention for CCS as possible mitigation option also led to opposition by several environmental and industrial interest groups (F7). However, this would rapidly change in the following episode, as a fierce debate on the deployment of onshore gas-fired power plants commenced.

\subsubsection{Episode 2: CCS, a fiercely debated technology}

In 1997, Norway adopted-but not yet ratified-the Kyoto Protocol (F4). In order to reach its Kyoto targets-i.e. an increase of GHG emissions limited to 1\% between 2008 and 2012 compared

\footnotetext{
${ }^{6}$ Norwegian research and industrial organisations were well represented in the emerging international CCS networks. This is for example manifested by their early membership of the IEA-GHG programme in 1991 and the Norwegian contributions to the first international conference on carbon dioxide removal (Turkenburg et al., 1992).
}

with the level in 1990 (NME, 1997) - the KLIMATEK funding program was established (F6). This program was administered by the Research Council of Norway and promoted R\&D of various low emission technologies. In the first 4 years of the program, nearly half of KLIMATEK's budget of $€ 3$ million per year went to CCSrelated projects (F6) (Sorheim, 2004). This funding typically led to an accumulated turnover by private parties of 3-4 times the funded value.

Among others, Kværner's post-combustion capture technology received funding through KLIMATEK to establish a laboratory research unit at SINTEF and a larger pilot unit at Statoil's 'K-lab' facility at the gas terminal in Kårstø (F2). This first pilot project in Norway for $\mathrm{CO}_{2}$ capture from exhaust gases ended in 1999 and resulted in several patents (F2). In that same period, Norway's other major technology company 'Aker Technology' started an oxyfuel capture $R \& D$ project based on a combined cycle gas turbine (F2). In this R\&D project, Aker established a partnership with the French turbine developer Alstom and they (financially) aligned with several energy companies (F3) (Ursin and Halvorsen, 2001). This consortium patented its "High Oxygen" technology in 1999 (F2).

The first substantial public-private research effort regarding $\mathrm{CO}_{2}$ storage is the Saline Aquifer $\mathrm{CO}_{2}$ Storage project (SACS, 2000), which ran between 1998-1999 (F2). This EU co-funded $€ 5$ million project (F6) was coordinated by Statoil and involved a long list of international oil, gas and energy companies, as well as research institutes $(F 3)^{7}$ (Karstad, 2002a). The main objective of this program was to monitor the $\mathrm{CO}_{2}$ behaviour at Statoil's storage site in the Utsira formation, which led to the world's first 3D seismic survey of $\mathrm{CO}_{2}$ in an aquifer (Torp and Gale, 2004).

In 1998, Norway's second largest oil company, Norsk Hydro, launched its Hydrokraft project (F1). This comprehended the development of a pre-combustion capture technology with an integrated reformer combined cycle for a proposed $1200 \mathrm{MW}$ power plant. ${ }^{8}$ Larsen and Ruud (2005) explain that the Hydrokraft project fitted rightly in the fierce political discussion about the two concessions received by power company Naturkrafta consortium of Statoil, Norsk Hydro and Statkraft-to build gasfired power plants. This debate was originally about whether or not to build these combined cycle plants, but after several influential environmental NGOs-including Bellona and Nature and Youth-introduced the concept of CCS in the public domain, it changed rapidly into whether to build these plants with or without CCS (Tjernshaugen, 2007). Particularly after Norsk Hydro started its 'cost-effective' Hydrokraft project, which made any other option look like 'stone age technology' (F4).

This elucidates that the ongoing R\&D activities had a vast impact on the political and public legitimacy for CCS technology (see Fig. 2). Influenced by the 'Joint action against gas-fired power plants', which is considered as the broadest environmental movement campaign of the decade (F7), the Norwegian pollution control authority (SFT) refused to issue the full emission permits required by Naturkraft to develop gas power in Norway (Tjernshaugen and Lee, 2004). This implied that the only way to comply was to build a CCS facility as an integral part of the power plant (F4). However, this implication caused a strong parliamentary opposition. Especially after Norsk Hydro's decision in 1999 to put the Hydrokraft project temporarily on hold, because of technical and financial difficulties. This political crisis resulted in the resignation of the minority government led by Bondevik in March 2000.

\footnotetext{
7 Important Norwegian actors besides Statoil included Industrikraft MidtNorge, Norsk Hydro, SINTEF and the Norwegian Geological Survey (SACS, 2000).

${ }_{8}$ The plant size was determined to use $60 \mathrm{MtCO}_{2}$ for pressure support at the Grane oil field over a 15-year period.
} 


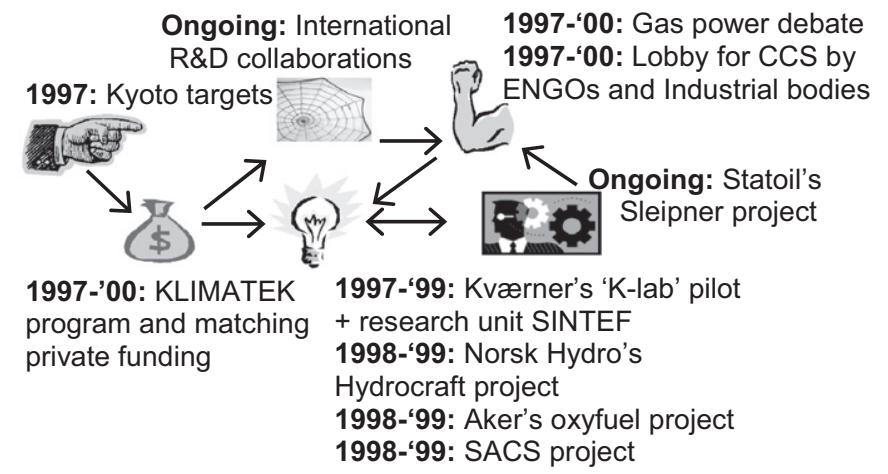

Fig. 2. Function interactions episode II: 1997-2000.

\subsection{Period $2000-2007$}

The situation regarding the deployment of gas power in Norway changed instantly after the Bondevik administration resigned in 2000. The interim government, led by Stoltenberg, favoured gas power and decided to issue full emission permits for Naturkraft's two power plants and another one for Industrikraft Midt-Norge. However, elections in 2001 brought Bondevik back in office, whose new administration was even more dedicated towards the deployment of CCS. This marks the start of the second period in this analysis, which lasts until 2008.

\subsubsection{Episode 3: dedication towards CCS}

Even though Bondevik could not reverse the decisions made by the Stoltenberg administration, energy policies changed quickly when he returned to power in 2001. After the policy negotiations following the election, it was announced that "no further concessions would be granted for fossil-fuelled plants without CCS" (Tjernshaugen, 2007). This was not only a clear statement to any organisation with plans to develop gas power, but also implied that the Norwegian government had to support the development of CCS to make its deployment viable (F4). Consequently, the budget for the development of environmental sound technologies in the KLIMATEK funding program was raised significantly (F6) and largely allocated to CCS R\&D (see Fig. 3).

In 2002, the $\mathrm{KMB} \mathrm{CO}_{2}$ project was launched (F2). The first phase (2002-2006) of this national competence-building project received $€ 13$ million funding and focused mainly on underground $\mathrm{CO}_{2}$ storage and enhanced oil recovery (EOR). In that same year, the SACS-II project (F2) was succeeded by the 3 year $\mathrm{CO}_{2}$ Store program (F2). This program, which centred on $\mathrm{CO}_{2}$ storage in aquifers, was co-funded by the EU (F6) and involved 19 international organisations from industry and research institutes (F3). Apart from these developments in $\mathrm{CO}_{2}$ storage research, the newly available funding program also supported the expansion of studies regarding $\mathrm{CO}_{2}$ capture.

After Norsk Hydro shelved its Hydrokraft technology, it started the Advanced Zero Emission Power (AZEP) project, which comprehended the development of a high-temperature oxyfuel gas turbine with membrane separation technology (Sundkvist and Eklund, 2005). This project (F2) was part of the Carbon Capture Program (CCP), an international program run by $8-10$ oil companies, with public support from the 5th Framework Program of the European Commission (F2), USA Department of Energy and the Reseach Council of Norway (Thomas and Benson, 2005). Another smaller Norwegian contribution to CCP was the NORCAP program, which tested several promising $\mathrm{CO}_{2}$ capture technologies (F2) (Sundset, 2003). The development of capture technologies continued when relatively small technology-based companies entered the market (F1), which resulted in the Zero

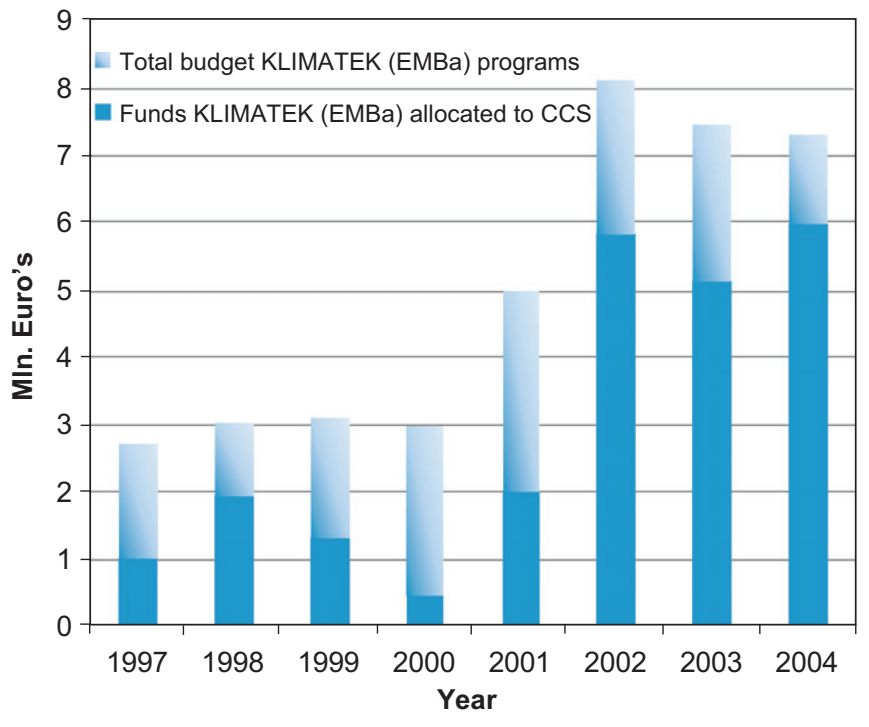

Fig. 3. Total budget KLIMATEK and EMBa funding programs, including the share for CCS R\&D (Sorheim, 2004). Note that in 2002, KLIMATEK became part of the EMBa funding program.

Emission Gas (ZEG) project $^{9}$ and the Zero Emission Norwegian Gas (ZENG) program (F2). ${ }^{10}$ Furthermore, Norwegian technology company Sargas, another newcomer in 2003, started the design of a post-combustion capture technology, based on patents from Siemens (F2).

Next to these ongoing R\&D efforts, Statoil announced its second commercial CCS project related to natural gas handling in 2001 (F1). The development of this project called Snøhvit ('Snow white') was motivated by Statoil's Sleipner project and the still existing carbon tax (see Fig. 4). The project comprises the transport of natural gas from the Snøhvit gas field to an onshore LNG refinery located in Hammerfest. There, the $\mathrm{CO}_{2}$ is separated from the gas and compressed. Instead of venting the $\mathrm{CO}_{2}$ to the atmosphere, which would increase Norway's GHG emissions by $2 \%, 700 \mathrm{kt} \mathrm{CO}_{2} /$ year is transported back to the sub-sea installation by pipeline and injected in an offshore geological formation below the gas reservoir (Maldal and Tappel, 2004).

Fig. 4 depicts the increasing interaction between system functions in this period. The ongoing lobbying activities by industrial and environmental interest groups led to changes in legislation (CCS compulsory for new fossil-fuelled power plants) and an increase in the available funds for CCS R\&D. This subsequently led to establishment of more research collaborations and $R \& D$ projects. The existing carbon tax and successful Sleipner project also triggered the development of a second large-scale CCS project called Snøhvit.

The Norwegian government had no specific legal framework for $\mathrm{CO}_{2}$ storage when Statoil initiated its Sleipner and Snøhvit projects. Therefore, existing mining regulations applied to them. This implies that Statoil is responsible for the stored $\mathrm{CO}_{2}$ as long as the field is in operation; after that, it will prepare the field to hand it over to the Norwegian government, which is then liable for the sequestered $\mathrm{CO}_{2}$. In the following and most recent episode, the transfer of liability for the stored $\mathrm{CO}_{2}$ was further refined when this issue was taken up in European directives (EC, 2008).

\footnotetext{
${ }^{9}$ ZEG is a joint venture between the IFE, CMR and Prototech that develops an integrated power production system, based on a high-temperature fuel cell, with $\mathrm{CO}_{2}$ removal and hydrogen production.

${ }_{10}$ The ZENG program is being co-developed by Lyse Energi, Nebb Engineering, Procom Venture and $\mathrm{CO}_{2}$-Norway and addresses the development of an oxyfuel combustion system.
} 
2001-'04: KLIMATEK \&

EMBa funding programs

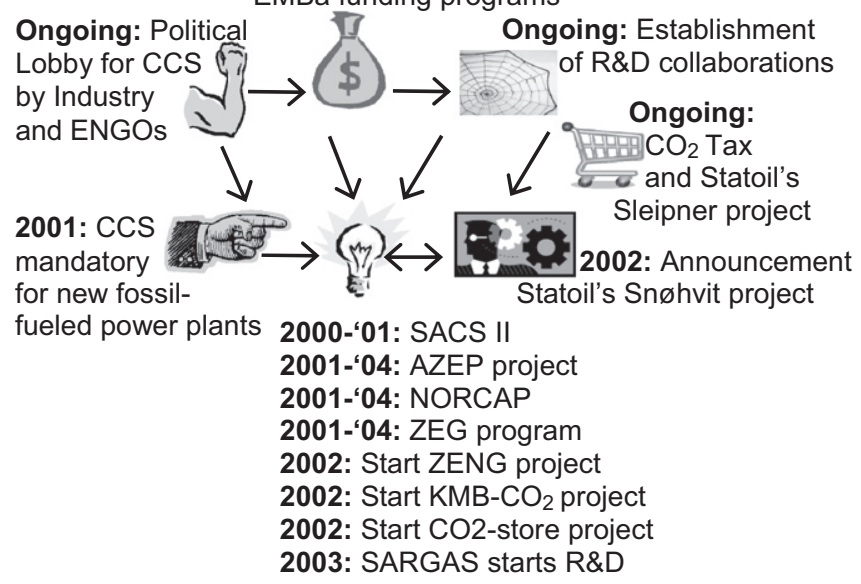

Fig. 4. Function interactions episode III: 2001-2004.

Moreover, important international legal issues related to the environment became clear under The London Convention and OSPAR treaties (Mace et al., 2007).

\subsubsection{Episode 4: visions for the future}

The interim government led by Stoltenberg gave permission for the construction of three gas-fired power plants without CCS in the year 2000. When he returned to power in 2005, his second administration set very ambitious emission reduction goals, i.e. to reduce GHG emissions 30\% by 2020 and to be carbon neutral in $2050^{11}$ (F4) (NME, 2007). This gave reason for a lot of dispute about the need to implement CCS in the new power plants, during the policy negotiations in September 2005. In the end, the 'Soria Moria policy declaration' stated that new concessions for gas-fired power should be based on CCS. It also suggested that the government should retrofit the Naturfkraft power plant at Kårstø $(420 \mathrm{MW})$ on own expenses and financially support the capture units of the other two power plants if they would be built (F1). Additionally, the declaration assured that the government would reinforce various policy measures and public financing to advance the realisation of infrastructure and test facilities for CCS (Tjernshaugen, 2007).

Following up on this declaration, the government financially supported a land-based laboratory for $\mathrm{CO}_{2}$ storage research on $\mathrm{CO}_{2}$ leakage pathways and monitoring techniques (F2). This research centre is led by SINTEF and involves seven other Norwegian research groups (F3). Furthermore, the government and Statoil agreed in October 2006 to establish a capture technology test centre at Mongstad (F2); Norway's major industrial refinery and $\mathrm{CO}_{2}$ emission source. This was part of the government's approval of a new combined heat and power (CHP) gas turbine $(630 \mathrm{MW})$ at Mongstad. The first step in the agreement is the realisation of test facilities in 2010; with the capacity to capture $100 \mathrm{ktCO}_{2} /$ year. The subsequent stage, which commences in 2014, involves the construction of a full-scale $\mathrm{CO}_{2}$ post-combustion capture installation in connection with the $\mathrm{CHP}$ plant, capturing more than $1.5 \mathrm{MtCO}_{2}$ annually.

Besides the establishment of these test centres and the further enrolment of Norwegian organisations in major international R\&D

\footnotetext{
${ }^{11}$ In an effort to reach the more stringent emission goals the Norwegian government implemented the first phase of a domestic emissions trading scheme (ETS), under the Greenhouse Gas Emission Trading Act. The scheme covers 10-15\% of all Norwegian GHG emissions, as industries covered by the carbon tax are not (yet) included (NME, 2005).
}

programs $^{12}$ (F3), many of the R\&D projects that were initiated in the beginning of the millennium were reinforced in this episode (F2). Important in this respect is the second phase of the prestigious $\mathrm{KMB} \mathrm{CO}_{2}$. This $€ 29$ million program named ' $\mathrm{BIG} \mathrm{CO}_{2}$ ' runs from 2007 to 2011 (Røkke, 2007). Furthermore, the consortium led by Norsk Hydro started in 2005 with the construction of a $100 \mathrm{~kW}$ demonstration plant of the oxyfuel technology developed in the AZEP project (F2). However, the project stopped 2 years later because of unsatisfying results. The more successful ZENG program is working towards the demonstration of an oxyfuel combustion system in a 50-70 MW gas-fired power plant; and the development of a hydrogen production system with integrated $\mathrm{CO}_{2}$ capture continues within the ZEG consortium.

The CLIMIT funding program financially supports most of this RD\&D. CLIMIT focuses on CCS technologies only, and its budget is roughly $€ 17.5$ million a year (F6). The budget is administered by the Research Council of Norway and Gassnova (2006). The latter is an intermediary organisation that acts on behalf of the government regarding the implementation of CCS demonstration projects (F3). ${ }^{13}$ Accordingly, Gassnova is an important funding partner in the development of AkerKværner's 'Just Catch' technology, which comprehends an amine-based post-combustion technology for combined cycle gas turbines (F2). AkerKværner and its consortium partners invested $€ 4$ million in this technology, which has to be demonstrated in Naturfkraft's $420 \mathrm{MW}$ gas turbine at Kårstø in 2009, capturing $100 \mathrm{ktCO}_{2}$ annually. If successful, the technology will be scaled up to a capacity of $1 \mathrm{MtCO}_{2} /$ year in 2012. The offshore Utsira and Johansen formations are being evaluated for storage of $\mathrm{CO}_{2}$ from Kårstø (and Mongstad).

AkerKværner was also involved-together with Statoil, Shell Norway, Norsk Hydro and climate change research institution CICERO-in a study called ' $\mathrm{CO}_{2}$ value chain' in 2005, focusing on $\mathrm{CO}_{2}$ capture and EOR (F2). The promising results of this study led to the announcement of the 'Halten $\mathrm{CO}_{2}$ project' by Statoil and Shell Norway in March 2006. The project involved an $860 \mathrm{MW}$ gas-fired power plant with CCS at Tjeldbergodden to power a methanol factory and offshore activities. The captured $\mathrm{CO}_{2}$ would be used for EOR at the Draugen and Heidrun oil fields. Although Shell and Statoil already invested $€ 50$ million in the project, it was put on hold in June 2007, as studies showed that in this case EOR would not be commercially viable.

Next to the interest of the oil and gas industry in developing new commercial CCS projects, several Norwegian utility companies, as well as power-intensive industries, applied for construction permits for fossil-fuelled power plants with CCS. The first application came from Hammerfest Energi in January 2005, which planned to build a $100 \mathrm{MW}$ gas-fired power plant based on the Sargas post-combustion technology (F1). However, in June 2007, the Norwegian Water Resources and Energy Directorate (NVE) decided not to grant a concession due to poor energy efficiency of the power plant. As depicted in Table 2, six other applications have been filed for CCS-based power plants to the Norwegian authorities. Although it is argued that if one of these projects gets approved, a power plant with full-scale $\mathrm{CO}_{2}$ capture could be

\footnotetext{
12 Norwegian organisations joined various international research initiatives, such as: CCP (Statoil \& Norsk Hydro); CASTOR (Statoil, SINTEF \& NTNU); ENCAP (Statoil, SINTEF \& NTNU); INCACO ${ }_{2}$ (SINTEF \& Statoil); $\mathrm{CO}_{2}$ RemMoVe (Statoil, SINTEF \& DNV); $\mathrm{CO}_{2}$ Sink (Statoil \& DNV); Dynamis (Statoil, SINTEF, Store Norske Spitsbergen Kullkompani \& NTNU); CACHET (Norsk Hydro \& SINTEF); and $\mathrm{CO}_{2} \mathrm{GeoNet}$ (SINTEF \& NTNU).

${ }^{13}$ Gassnova is also responsible for the increasing number of gatherings on CCS (F3). For example, Gassnova co-organised the world's largest international CCS conference in Trondheim (GHGT-8, 2006).
} 
Table 2

Proposed CCS projects in 2008 related to power generation in Norway (NVE, 2008)

\begin{tabular}{|c|c|c|c|}
\hline Applicant(s) & $\begin{array}{l}\text { Plant size } \\
(\mathrm{MW})\end{array}$ & Fuel & Location \\
\hline BKK & 450 & Gas & Mongstad \\
\hline Skagerak Kraft & 1000 & Gas & Grenland \\
\hline Industrikraft Møre & 450 & Gas & Elnesvågen \\
\hline Haugaland Kraft & $400-800$ & Coal & Haugalandet \\
\hline $\begin{array}{l}\text { Skagerak Kraft, Fortum Power, } \\
\text { Østfold Energi }\end{array}$ & $400-1100$ & Gas & Slagentangen \\
\hline $\begin{array}{l}\text { Eramet, Sargas, Sør Norge } \\
\text { Aluminum, Tinfos }\end{array}$ & 380 & Coal & Hordaland \\
\hline
\end{tabular}

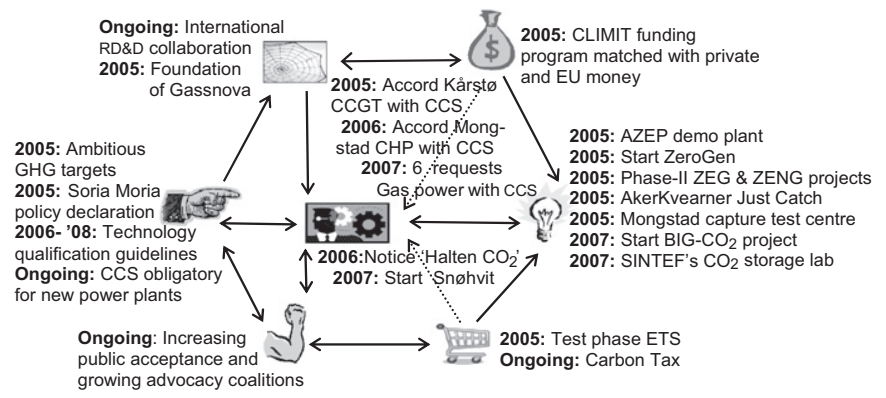

Fig. 5. Function interactions episode IV: 2005-2008.

ready in 2015, all applicants are still awaiting the decision of the NVE. ${ }^{14}$ Therefore, none of the organisations depicted in Table 2 has made an investment decision yet.

This leads to the odd case where the Norwegian government is at present the only party investing in full-scale deployment of CCS related to power generation (in Mongstad and Kårstø). This is partly the result of a broad political consensus that CCS will play a key role in Norway's low-emissions future ( $F 7$ ). A European survey showed that of all European countries, CCS plays by far the greatest-and still increasing-role in the national climate change debate in Norway (Shackley et al., 2007). The latter is nicely illustrated by Prime Minister Stoltenberg in his new years speech on the 1st of January 2007, in which he compared CCS developments in Norway with the moon landing of the US in 1969 (F4); "It is our vision that within seven years we will have put in place capture and storage technology. This will be an important breakthrough in the efforts to reduce GHG emissions in Norway, and once we succeed, I am convinced that the rest of the world will follow our example. This is a major project for our country. It is our moon landing."

Fig. 5 depicts the increasing-and more complex-positive feedback between system functions in the most recent episode of Norway's pioneering history in the field of CCS. It shows that the more stringent $\mathrm{CO}_{2}$ emission reduction targets, the development of standards for CCS and supportive legislation led to increased funding for CCS RD\&D and created legitimacy for CCS. Both processes were important for the development of additional large-scale CCS RD\&D projects.

Despite the growing complexity due to an increased amount of activity regarding all system functions, the four distinguished episodes in the evolution of the CCS innovation system show a

\footnotetext{
${ }^{14}$ Standards and qualification guidelines for CCS technologies are being developed by the Norwegian verification foundation (DNV) in cooperation with the authorities and industry.
}

similar kind of positive interaction pattern between the system functions. As a consequence of guiding emission reduction targets (F4) and an increasing legitimacy to support CCS technologies (F7), the government provided either financial resources $(F 6)$ or market incentives (F5). This resulted in a rising number of R\&D programs $(F 2)$ and triggered entrepreneurial activities (F1). These research and commercial projects were done in strong partnerships (F3), which in turn created more legitimacy for CCS (F7). Thereby reinforcing this virtuous cycle.

\section{Current innovation system performance}

The dynamic patterns in the growth of the Norwegian CCS innovation system show that the early dedication of the national government to reduce Norway's $\mathrm{CO}_{2}$ emissions has led to a remarkable consistent build-up of an innovation system around CCS technologies. However, this functional pattern does not guarantee a thriving development of CCS in the future. The Norwegian CCS innovation system may face recent challenges that obstruct a further expansion of the system.

In order to identify these possible impediments, the main actors composing the innovation system have been asked to reflect upon the ongoing activities regarding CCS and rate their level of satisfaction with the fulfilment of a particular system function. ${ }^{15}$ All ratings are on a scale of $1-5$, whereby 5 equals high level of satisfaction. Based on these expert judgements, mechanisms that are currently inducing, or blocking the further development of CCS in Norway can be identified. In order to put the present strengths and weaknesses of the innovation system into perspective, the progress in function fulfilment is detailed for each function. Thereby making use of the two distinctive time periods in the development of CCS in Norway.

\subsection{Entrepreneurial activity}

The entrepreneurs in the first period consisted of Norway's largest oil companies-i.e. Statoil and Norsk Hydro-and technology vendors Aker and Kværner. Although, its mergers and Statoil Hydro preserved their dominant position in the Norwegian innovation system in the second period, the amount of foreign companies entering the system increased significantly during that time. Moreover, the analysis shows that in more recent years the field of CCS also became interesting for small to medium enterprises-resulting in projects like ZEG and ZENG-and that the power sector is now better represented in the innovation system, than in the early days.

The entrepreneurial activities in the first period were centred around gas separation and $\mathrm{CO}_{2}$ storage in aquifers as a result Statoil's Sleipner project. The success of this project has led to Statoil's second CCS project-i.e. Snøhvit—related to (liquid) natural gas handling, which started in 2007. The third and even more ambitious Halten $\mathrm{CO}_{2}$ project, however, has been put on hold due to financial difficulties. The same holds for CCS projects related to power generation that have been proposed by several power companies. At present, only the Norwegian government announced its plans to invest in the full-scale deployment of CCS linked to gas power production (at Kårstø and Mongstad).

This implies that, despite the growing amount of entrepreneurs, the number as well as the diversity of demonstration and commercial projects is small. Consequently, the 'entrepreneurial activity' in Norway is with an average score of 2.7 the lowest rated

\footnotetext{
${ }^{15}$ For a more thorough description of our method, we refer to our analytical framework (Section 2.1.)
} 
function by the 20 key stakeholders that participated in this study. The low standard deviation (SD) of 0.7 underlines the consensus that the lack of large-scale CCS projects in relation to power generation and EOR is the most important impediment for a higher rating.

\subsection{Knowledge development}

While advocating the demonstration of several promising technologies, the respondents stress the importance to continue laboratory research. The current research programs and technology test centres cover a wide variety of techniques for capture, transportation and storage of $\mathrm{CO}_{2}$. The number and size of $\mathrm{R} \& \mathrm{D}$ projects increased considerably in the past decade, but the focus has been mainly on aquifer storage, gas separation and $\mathrm{CO}_{2}$ capture related to gas power production. Many Norwegian organisations-e.g. SINTEF and NTNU-accumulated strong competences in these research areas, which can be seen as Norway's competitive advantage in relation to other nations.

Although some experts stress the need of diversifying Norwegian research efforts towards capture technologies for coal-fired plants_-as they have a larger world market potentialthe knowledge created in Norway is considered as being of very high standard. Field experts generally praise the quality Norwegian CCS research and therefore this function received a relatively high rating of 3.9 with a SD of 0.8 . It is hard to identify impediments in the fulfillment of this function other than the need to move several preferred technologies further up the innovation chain and enhance learning by doing.

\subsection{Knowledge diffusion through interaction}

In both periods, organisations had two main reasons to establish partnerships. First, to share the relatively high costs (and investment risks) related to CCS development. Second, the technological challenges involved in the development of particularly capture technology, as well as the integration of different fields of expertise (capture, transport and storage of $\mathrm{CO}_{2}$ ), entail to share knowledge and competences. Therefore, project networks typically comprise a high number of diverse organisations. Furthermore, the Norwegian CCS innovation system is strongly embedded in global CCS networks. Not only by Norwegian organisations participating in international programs, but also because of the large number of international parties involved in CCS projects on (and under) Norwegian soil. In comparison to the first period, these (inter)national CCS networks became larger and 'denser' in more recent years.

Despite their growing complexity, the Norwegian CCS networks are characterized as particularly open and trustworthy. With the foundation of Gassnova halfway the second period, industry could rely on an effective government body for support when entering, or acting in the CCS innovation system. Gassnova stimulated knowledge exchange by creating network-building arenas, which resulted in an increasing number of CCS platforms and gatherings. Even so, it was noted that commercial interest and the protection of intellectual property hinder an optimal flow of knowledge between the actors attending these conferences, the performance of this function receives a score of 4.0 (SD of 0.8 ), which is the second highest rating of all functions.

\subsection{Guidance}

In 1987, the report 'our common future' of the Brundtland Commission addressed the growing tension between economic growth and ecological deterioration. After chairing the commission,
Brundtland became Norway's prime minister from 1990-1996 and she agreed that 'Norway's $\mathrm{CO}_{2}$ emissions were to be limited so that they would not exceed the 1989 level in the year 2000' (NME, 1994). However, clear statements on how to achieve these GHG emission reduction targets-let alone the role of CCS - were practically absent in the first half of the nineties. Moreover, Naturkraft received two concessions to build gas-fired power plants in 1996, without mentioning the option for CCS.

In 1997, Norway adopted the Kyoto Protocol (F4). However, the construction of two gas-fired plants would put Norway further away from reaching its Kyoto targets, i.e. an increase of GHG emissions limited to $1 \%$ between 2008 and 2012 compared with the level in 1990 (NME, 1997). The following 'gas power debate' resulted eventually in the resignation of the minority government led by Bondevik, when faced with parliamentary opposition to its strict gas power emission terms. In contrast, the succeeding interim Stoltenberg government issued full emission permits for the construction of three gas-fired power plants in 2000.

Elections in 2001 brought Bondevik back in office, whose new administration was even more dedicated towards the deployment of CCS and he announced that no additional concessions would be granted for fossil-fuelled power plants without CCS. This fitted rightly in the ambitious mid- and long-term emission targets, which have been reformulated several times in the second period, resulting in the goal to reduce $\mathrm{CO}_{2}$ emissions with $30 \%$ in 2020 and to be carbon neutral in 2050. Following his predecessor, the second Stoltenberg administration emphasised the importance of CCS in realizing these emission reductions. The latter is nicely illustrated by his new years speech in 2007, where he calls the development of CCS technology for the Mongstad plant "Norway's lunar landing project".

Nevertheless, it is unknown to what extent the Norwegian government can live-up to these high expectations, as it remains uncertain how many power plants with CCS will be built and in what way the Norwegian government is going to support this. Therefore, the guidance in the development of CCS is rated with a 3.0. However, the relatively high SD of 1.1 indicates that there is little consensus on this rating. This is mainly caused by the duality in strong generic guidance-i.e. CCS has an important role to play Norway's low-emissions future-and the lack of specific guidancei.e. supportive policy instruments and short-term goals-, as CCS is not (yet) being adopted as a result of normal market forces.

\subsection{Market formation}

The introduction of a carbon tax proved to be a very effective incentive to encourage $\mathrm{CO}_{2}$ storage operations in the North Sea. Additionally, it triggered the development of capture solutions for initially offshore- and later onshore-gas- based power production. Despite these developments, the present high costs of $\mathrm{CO}_{2}$ capture, is one of the main barriers to its application. So far, it appeared that the carbon tax of approximately $€ 40 /$ tonne $\mathrm{CO}_{2}$ is not sufficient to initiate commercial CCS projects related to power generation. Also, the introduction of a domestic GHG Emissions Trading Scheme (ETS), which could be linked to the EU ETS in later stage, is not likely to create enough incentive for private actors to engage in such projects on a short term.

Although the Norwegian government agreed to finance the capture unit of the combined cycle gas turbines at Kårstø and Mongstad, its willingness to financially support other initiatives is uncertain. The amount of public money that will be allocated to realise relevant infrastructure is also debated. Therefore, the strong government statement, at the beginning of the millennium, not to issue emission permits for gas-based power plants, does not yet seem to create a commercial market for gas power production 
with CCS. Therefore, the 'formation of markets' is rated with a 2.9. However the SD is 1.3, meaning that there is no clear consensus. The latter can be explained by the successful execution of CCS projects related to natural gas handling due to the fixed carbon tax on the one hand, and the financial difficulties that are encountered by the large-scale application of CCS linked to power production on the other hand.

\subsection{Resource mobilisation}

In 1997, the Research Council of Norway established the KLIMATEK funding program with a budget of approximately $€ 4.5$ million for R\&D of CCS technologies in the first 4 years. In the second period, similar types of subsidiary schemes succeeded this program and the financial support for CCS increased up to $€ 6$ million per annum. In 2005 that the first funding mechanism solely allocated to CCS was established. This CLIMIT program with a budget of $€ 17.5$ million a year meant a substantial increase in the total funds available for CCS RD\&D, as these finances were matched with private investments and European funding. In fact, Norway has got by far the highest level of funding for CCS relative to GDP, compared with other high-income countries (Tjernshaugen, 2006). However, considering the need to shift from to learning by doing, many actors-especially the technology developing industries-would like to see more funding for demonstration projects.

The availability of financial resources was rated as 3.5 with a $\mathrm{SD}$ of 0.9. Insufficient funds for large-scale projects were mentioned as the most important barrier for a higher rating. Field experts rated the availability of human resources separately. In contrast to financial capital, the accessibility to human capital received a low rating; 2.7 with a SD of 0.8 . The respondents are in agreement on the increasing scarcity of skilled (technical) personnel in CCS research.

\subsection{Creation of legitimacy}

During the development of Statoil's ground-breaking Sleipner project, some environmental groups, including Greenpeace, placed a critical note by the 'dumping' of $\mathrm{CO}_{2}$ in the Utsira formation. This was not beneficial for the already limited political and public awareness of $\mathrm{CCS}$ as a potential $\mathrm{CO}_{2}$ mitigation option. However, this would rapidly change in 1997, as a fierce debate on the deployment of onshore gas-fired power plants commenced. Important in this debate was the contribution of environmental groups, which held different views on CCS.

Norway's largest environmental NGO: 'Friends of the Earth (FoE)' followed Greenpeace in its opposition towards CCS. They reason that continued production of electricity from fossil fuels with CCS lengthens the dependence on non-renewable resources. Although these organisations have been critical, they haven't been very vocal in Norway. On the other hand, CCS was supported vigorously by 'Nature and Youth', formally the youth branch of FoE Norway. Also the environmental NGO Bellona has pushed CSS very actively since the late 1990s. They followed a pragmatic approach towards the oil and gas industry and emphasised the economic potential of CCS in combination with EOR; thereby contributing to the acceptance of CCS by society. ${ }^{16}$

Equally important and characterizing both periods, is that CCS is favoured by a powerful coalition of Norwegian industrial peak

\footnotetext{
${ }^{16}$ Also the fact that the $\mathrm{CO}_{2}$ is stored in offshore reservoirs contributed to a more positive stand towards CCS by the general public. As there are no communities directly exposed to the possible risks of $\mathrm{CO}_{2}$ leakage from the reservoirs. In other words, there is no reason for 'Not In My Back Yard' opposition to the current CCS projects.
}

organisations (Norwegian Confederation of Trade Unions) and Norsk Industri (Federation of Norwegian Industries). These partners are closely aligned with the regional electrochemical industries, being interested in using more natural gas in their production processes. Together with the national oil companies, these resources-based industrial interest groups occupy a privileged role in Norwegian politics and the Norwegian innovation system (Narula, 2002). These industrial organisations could benefit from CCS as one outlet for their substantial $\mathrm{CO}_{2}$ emissions and therefore they perform a powerful lobby for its deployment in political arenas.

Besides lobbying activities of various environmental and industrial interest organisations, the increased public awareness of climate change and the more stringent GHG emission reduction targets formulated by governments have created more legitimacy to financially support the development of CCS with public money. Furthermore, the government's work on a supportive legal framework, including the development of qualification guidelines for CCS technologies (approximating similar EU directives), as well as the settlement of international legal issues under the London Convention and OSPAR treaty, created more legitimacy for the transfer of liability of the stored $\mathrm{CO}_{2}$ to the Norwegian authorities. As a result, field experts give the creation of legitimacy for CCS a rating of 4.1 (SD of 0.8), which is the highest rating of all functions.

\section{Identification of key policy issues}

The performance assessment of the Norwegian CCS innovation system shows that the extensive knowledge base, which has been accumulated over the past two decades, has not yet been valorised by entrepreneurs to explore the market for CCS concepts linked to power generation and EOR. This indicates that the build-up of the innovation system has entered a critical phase that is decisive for a further thriving development of CCS in Norway. In order to move the CCS innovation system through this present difficult episode and deploy more advanced CCS concepts; it is necessary to direct policy initiatives at the identified weak system functions, i.e. entrepreneurial activity, market formation and guidance (see Fig. 6).

In order to improve its guiding role, the Norwegian government can foster the implementation of CCS technologies by stating short-term objectives in addition to the mid-term GHG emission reduction targets and long-term visions. Furthermore, it seems desirable to provide clarity on the set of policy instruments that will be used to reach these goals. The latter is important for the involvement of private parties in the development of CCS linked to gas power. The industrial sectors that may apply CCS in their daily operations should be able to rely on a long-lasting change in the institutional structure of the innovation system that creates a clear market for CCS. Temporal subsidies, or taxes that are applied at present, do not seem to be strong enough to deal with the relatively high costs of CCS.

Policies can foster market formation and entrepreneurial activity by financially supporting learning by doing, i.e. by establishing more demonstration projects. In this way the technology is brought down its learning curve. This is necessary to bring about the required cost reductions and performance improvements for the technology to enter the market. The current Norwegian (carbon) tax system and the proposed ETS, provide opportunities to create such financial incentives. This can be done by reallocating the tax revenues of the oil and gas industry to the implementation of full-scale CCS projects and the construction of an pipeline infrastructure for $\mathrm{CO}_{2}$ transportation. 


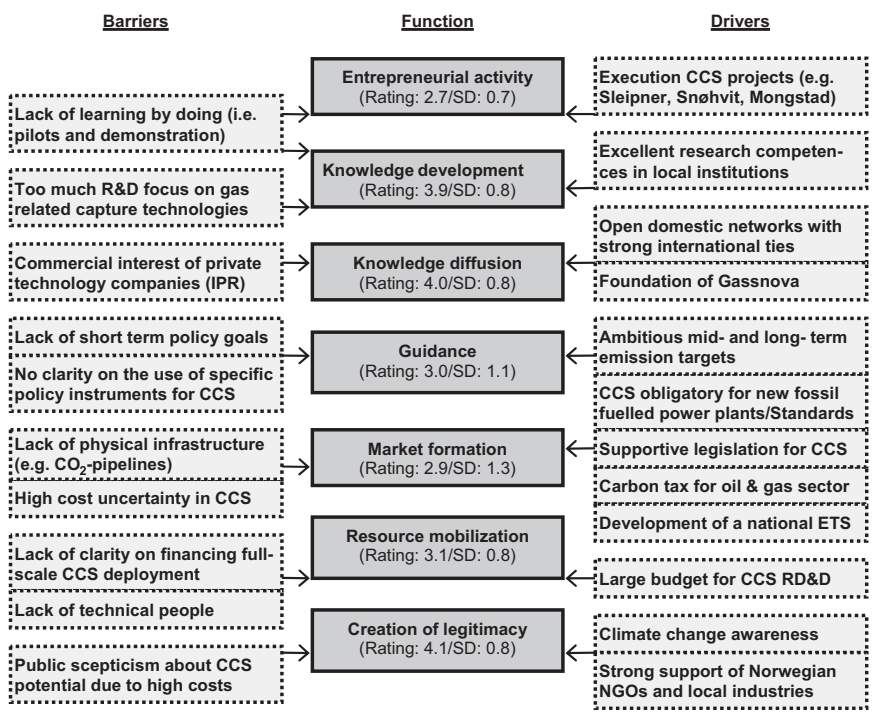

Fig. 6. Drivers and barriers for CCS development in Norway.

\section{Discussion and conclusions}

The analysis of the Norwegian CCS innovation system provides insights into the relations between the historical dynamics of the system and the system's current performance. The results show that the early dedication of the national government to reduce Norway's $\mathrm{CO}_{2}$ emissions has led to a remarkable consistent buildup of a national CCS innovation system. Throughout the evolution of the system, conditions have been supportive for this to happen. Converging perspectives on the importance of CCS in the Norwegian energy system by researchers, (industrial) entrepreneurs, the national government and somewhat later also environmental groups, has resulted in a steady growth of the innovation system as a whole. This is visible through the entry of new actors; extension of the knowledge base; successful entrepreneurial projects; increasing availability of public money; changes in legislation; creation of strong advocacy coalitions; and a guiding government fostering the development of CCS.

The positive system dynamics point out that strong advocacy coalitions of industrial peak organisations (e.g. Statoil, Hydro, AkerKværner) and several environmental NGOs (e.g. Bellona and ZERO), as well as the national government (or its representative body Gassnova) have been successful in stimulating the creation of technological knowledge (e.g. by SINTEF and NTNU) in comprehensive national and international consortia (e.g. SACS and $\mathrm{BIG} \mathrm{CO}_{2}$ ); and in triggering entrepreneurs to apply this knowledge in the market (e.g. Statoil's Sleipner \& Snøhvit projects and AkerKværner's 'Just Catch' technology). The latter is done by providing market incentives (e.g. carbon tax and performance standards) and financial stimuli (e.g. KLIMATEK and CLIMIT), but also by creating a supportive legal framework (e.g. resolving liability issues for the sequestered $\mathrm{CO}_{2}$ ) and the realisation of relevant infrastructure. These actions are legitimised by the country's strong climate policies (e.g. the reduction of $\mathrm{CO}_{2}$ emissions of $30 \%$ by 2020 compared with 1990), which in turn guide the search for sustainable solutions.

The build-up of a well-performing CCS innovation system has given Norway an international leadership position in the field of CCS. However, it is realised by the key stakeholders participating in the study that Norway's leading role in the development of CCS should not be taken for granted. Their evaluation of the current innovation system performance identified several barriers that may block continuing positive system dynamics. The results provide a clear understanding of the current impediments in the CCS innovation system and stress the need to direct policy initiatives at the identified weak system functions-i.e. guidance, entrepreneurial activity and market formation-to enhance the performance of the system.

In order to improve its guiding role, the Norwegian government could provide more clarity on the set of policy instruments that will be used to involve private parties in the development of CCS linked to power production and EOR. These industrial sectors that may apply CCS in their daily operations should be able to rely on a long-lasting change in the institutional structure of the innovation system that creates a clear market for CCS.

Policies can foster market formation and entrepreneurial activity by financially supporting learning by doing, i.e. by establishing more demonstration projects linked to power generation and EOR. This is necessary to bring about the required cost reductions and performance improvements for the technology to enter the market. Although the current subsidies and taxes do not seem to be strong enough to deal with the relatively high costs of $\mathrm{CO}_{2}$ capture at power facilities, they do provide opportunities to create such financial incentives. For instance, the (carbon) tax revenues of the oil and gas industry can be re-allocated to the implementation of full-scale CCS projects.

However, the choice for a specific set of policy instruments should not only be assessed to the extent of how they manage to remedy poor functionality in the CCS innovation system, but should also take into account the possible negative effects on the development of other (competing) sustainable energy technologies. In that respect, this study has got a narrow perspective, as it only focuses on CCS technologies.

Another point of discussion is the geographical focus on Norway, as foreign activities in the field of CCS can be determinative for the choice of policy instruments that will be employed to enhance the application of CCS Norway. Whether to buy foreign technology, or rely on 'home-grown' solutions and expertise is at the heart of this policy decision. It might be possible that new and more influential innovation system dynamics start off as part of international developments. Due to the extensive international relationships of the Norwegian CCS innovation system, a policy maker at the national level should be aware of the increasing importance of these global innovation processes for local activities.

In order to analyse these global trends in the development of CCS technologies, it is desirable to apply the analytical framework presented in this study to other countries as well. These analyses would not only allow for cross-national comparison on a function level-e.g. differences between R\&D expenditures, technological focus, or market incentives-, but would also provide an opportunity to learn from other countries in overcoming the obstacles encountered in the development of CCS technologies.

Despite the technological and geographical delineations applied in this study, the results contain important insights in the current performance of the Norwegian CCS innovation system and identified several key policy issues that need to be addressed in order to enhance positive innovation system dynamics. These insights are not only of specific use for policy decisions regarding the deployment of CCS in Norway, but can also be of value for decision makers in other countries that wish to foster the development of CCS technologies.

\section{Acknowledgements}

We would like to gratefully acknowledge Andreas Tjernshaugen (CICERO), for his cooperation with and supervision of Jochem van Ruijven during his internship at the Center for International 
Climate and Environmental Research Oslo (CICERO). Furthermore, we thank Trygve Riis (The Norwegian Research Council) for his inspiring comments on earlier versions of this paper, as well as two anonymous reviewers of this journal who put in a lot of effort to improve the quality of this paper. This research is part of the CATO program, the Dutch national research program on CCS.

\section{References}

Alkemade, F., Kleinschmidt, C., Hekkert, M.P., 2007. Analysing emerging innovation systems: a functions approach to foresight. International Journal of Foresight and Innovation Policy 3 (2), 139-168.

Asheim, B.T., Isaksen, A., 1997. Localisation agglomeration and innovation: towards regional innovation systems in Norway? European Planning Studies 5, 299-330.

Bergek, A., Hekkert, M.P., Jacobsson, S., 2006. Functions in innovation systems: a framework for analysing energy system dynamics and identifying goals for system-building activities by entrepreneurs and policy makers. Innovations in energy systems, Oxford.

Bergek, A., Jacobsson, S., Carlsson, B., Lindmark, S., Rickne, A., 2008. Analyzing the functional dynamics of technological innovation systems: a scheme of analysis. Research Policy 37, 407-429.

Berger, B., Sundset, T., Torp, T., 2003. The Sleipner \& SACS experience. In: Presentation at NorCap Seminar, Trondheim.

Burton, I., 1987. Our common future. Environment 29 (5), 25.

Carlsson, B., Stankiewicz, R., 1991. On the nature, function and composition of technological systems. Journal of Evolutionary Economics 1 (2), 93-118.

Doloreux, D., Parto, S., 2004. Regional Innovation Systems: A critical review. Maastricht Economic Research Institute on Innovation and Technology (MERIT), Maastrich, The Netherlands.

EC, 2008. Proposal for a directive of the European arliament and of the council on the geological storage of carbon dioxide and amending Council Directives. Regulation (EC) no 1013/2006. European Commission, Brussels.

Edquist, C., 2001. The systems of innovation approach and innovation policy: an account of the state of the art. Lead paper presented at the DRUID conference, under the theme 'National Systems of Innovation. Institutions and Public Policies'. Aalborg, Denmark.

Edquist, C., 2004. Reflections on the systems of innovation approach. Science and Public Policy 31 (6), 485-489.

Falk-Pedersen, O., Dannstrom, H., 1997. Separation of carbon dioxide from offshore gas turbine exhaust. Energy Conversion and Management 38 (Suppl. 1), S81-S86.

Falk-Pedersen, O., Bjerve, Y., Glittum, G., Ronning, S., 1995. Separation of carbon dioxide from offshore gas turbine exhaust. Energy Conversion and Management 36 (6-9), 393-396.

Foxon, T.J., Gross, R., Chase, A., Howes, J., Arnall, A., Anderson, D., 2005. UK innovation systems for new and renewable energy technologies: drivers, barriers and systems failures. Energy Policy 33 (16), 2123-2137.

Freeman, C., 1987. Technology Policy and Economic Performance. Pinter Publishers, London.

Gassnova, 2006. Norwegian Gas Power Technology RD\&D Program CLIMIT: Work Programme 2006, Gassnova and the Research Counsil Norway.

Geels, F.W., 2002. Technological transitions as evolutionary reconfiguration processes: a multi-level perspective and a case-study. Research Policy 31 (8-9), 1257-1274.

GHGT-8, 2006. Conference proceedings. In: Eighth International Conference on Greenhouse Gas Technologies, Trondheim, Elsevier.

Godoe, H., Nygaard, S., 2006. System failure, innovation policy and patents: fuel cells and related hydrogen technology in Norway 1990-2002. Energy Policy 34 (13), 1697-1708

Hekkert, M., Negro, S., 2008. Functions of innovation systems as a framework to understand sustainable technological change: empirical evidence for earlier claims. Technological Forecasting \& Social Change, doi:10.1016/ j.techfore.2008.04.013.

Hekkert, M.P., Harmsen, R., de Jong, A., 2007a. Explaining the rapid diffusion of Dutch cogeneration by innovation system functioning. Energy Policy 35 (9), 4677-4687.

Hekkert, M.P., Suurs, R.A.A., Negro, S.O., Kuhlmann, S., Smits, R.E.H.M., 2007b. Functions of innovation systems: a new approach for analysing technological change. Technological Forecasting and Social Change 74 (4), $413-432$.

Holloway, S., Heederik, J.P., van der Meer, L.G.H., Czernichowski-Lauriol, I., Harrison, R., Lindeberg, E., Summerfield, I.R., Rochelle, C., Schwarzkopf, T., Kaarstad, O., Berger, B., 1996. The underground disposal of carbon dioxide. Joule II Project no. CT92-0031. Nottingham, UK.

IEA, 2005. Energy Policies of IEA Countries-Norway 2005 Review. International Energy Agency (IEA), Paris.

IPCC, 2005. IPCC Special Report on Carbon Dioxide Capture and Storage. B. Prepared by Working Group III of the Intergovernmental Panel on Climate Change [Metz and H. C. d. C. O. Davidson, M. Loos, and L. A. Meyer (eds.)]. Intergovernmental Panel on Climate Change.

Jacobsson, S., 2008. The emergence and troubled growth of a 'biopower' innovation system in Sweden. Energy Policy 36, 1491-1508.
Jacobsson, S., Bergek, A., 2004. Transforming the energy sector: the evolution of technological systems in renewable energy technology. Industrial and Corporate Change 13 (5), 815-849.

Jacobsson, S., Johnson, A., 2000. The diffusion of renewable energy technology: an analytical framework and key issues for research. Energy Policy 28 (9) 625-640.

Jacobsson, S., Andersson, B.A., Bångens, L., 2002. Transforming the energy system-the evolution of the German technological system for solar cells. SPRU Science and Technology Policy Research, Brighton.

Johnson, A., 2001. Functions in Innovation System Approaches. In: Paper for DRUID's Nelson-Winter Conference, Aalborg, Denmark.

Johnston, P., 1999. Ocean Disposal/Sequestration of Carbon Dioxide from Fossil Fuel Production and Use: An Overview of Rationale, Techniques and Implications. Greenpeace Research Laboratories, Amsterdam.

Karstad, O., 1992. Emission-free fossil energy from Norway. Energy Conversion and Management 33 (5-8), 781-786.

Karstad, O., 2002a. Geological storage, including costs and risks, in saline aquifers. In: Paper Presented at the IPCC Workshop on Carbon Dioxide Capture and Storage, Geneva.

Karstad, O., 2002b. The Sleipner and Snohvit $\mathrm{CO}_{2}$ Projects and Possible Future Roles of Underground Storage. Statoil, Trondheim, Norway.

Kemp, R., Loorbach, D., Rotmans, J., 2007. Transition management as a model for managing processes of co-evolution towards sustainable development. International Journal of Sustainable Development and World Ecology 14 (1), 78-91.

Kjærland, F., 2007. A real option analysis of investments in hydropower-the case of Norway. Energy Policy 35 (11), 5901-5908.

Kongsjorden, H., Karstad, O., Torp, T.A., 1998. Saline aquifer storage of carbon dioxide in the Sleipner project. Waste Management 17 (5-6), 303-308.

Korbol, R., Kaddour, A., 1995. Sleipner vest $\mathrm{CO}_{2}$ disposal-injection of removed $\mathrm{CO}_{2}$ into the Utsira formation. Energy Conversion and Management 36 (6-9), 509-512.

Larsen, O.M., Ruud, A., 2005. HydroKraft: Mapping the Innovation Journey in Accordance with the Research Protocol of CondEcol. Program for Research and Documentation for a Sustainable Society (ProSus). Centre for Development and the Environment, University of Oslo, Oslo, pp. 1-49.

Lundvall, B.A., 1992. National Systems of Innovation-Toward a Theory of Innovation and Interactive Learning. Pinter Publishers, London.

Mace, M.J., Hendriks, C., Coenraads, R., 2007. Regulatory challenges to the implementation of carbon capture and geological storage within the European Union under EU and international law. International Journal of Greenhouse Gas Control 1 (2), 253-260.

Maldal, T., Tappel, I.M., 2004. $\mathrm{CO}_{2}$ underground storage for Snohvit gas field development. Energy 29 (9-10), 1403-1411.

Malerba, F., 2002. Sectoral systems of innovation and production. Research Policy 31, 247-264.

Markard, J., Truffer, B., 2008. Technological innovation systems and the multilevel perspective: towards an integrated framework. Research Policy 37, 596-615.

Narula, R., 2002. Innovation systems and 'inertia' in R\&D location: Norwegian firms and the role of systemic lock-in. Research Policy 31 (5), 795-816.

Negro, S.O., Hekkert, M.P., Smits, R.E., 2007. Explaining the failure of the Dutch innovation system for biomass digestion-A functional analysis. Energy Policy 35 (2), 925-938.

Negro, S.O., Suurs, R.A.A., Hekkert, M.P., 2008. The bumpy road of biomass gasification in the Netherlands: explaining the rise and fall of an emerging innovation system. Technological Forecasting and Social Change 75 (1), 57-77.

Nelson, R.R., 1992. National innovation systems: a retrospective on a study. Industrial and Corporate Change 2, 347-374.

NME, 1994. Norway's National Communication under the Framework Convention on Climate Change-September 1994. Ministry of the Environment, Oslo, pp. 1-66.

NME, 1997. Norway's Second National Communication under the Framework Convention on Climate Change-April 1997. Ministry of the Environment, Oslo.

NME, 2005. Norway's Fourth national Communication under the Framework Convention on Climate Change. Ministry of the Environment, Oslo, pp. 1-92.

NME, 2007. Norwegian climate policy. Summary in English: Report no. 34 (2006-2007) to the Storting. Ministry of the Environment, Oslo.

NVE, 2008. Meldinger og søknader om varmekraft og gassrørledninger. Norwegian Water Resources and Energy Directorate.

OED, 2007. Fact Sheet: Carbon Capture and Geological Storage. The Royal Norwegian Ministry of Petroleum and Energy, Oslo.

Røkke, N., 2007. BIGCCS Plattformen BIGCCS Plattformen-basis for videre vekstbasis for videre vekst. $\mathrm{CO}_{2}$ Seminar Teveltunet, Teveltunet, Norway.

SACS, 2000. SACS - Saline Aquifer $\mathrm{CO}_{2}$ Storage. Final Technical Report.

Shackley, S., Waterman, H., Godfroij, P., Reiner, D., Anderson, J., Draxlbauer, K., de Conick, H., Groenenberg, H., Flach, T., Sigurthorsson, G., 2007. Stakeholder Perceptions of $\mathrm{CO}_{2}$ Capture and Storage in Europe: Results from the EU-funded ACCSEPT Survey, The ACCSEPT Project.

Smith, A., Stirling, A., Berkhout, F., 2005. The governance of sustainable sociotechnical transitions. Research Policy 34 (10), 1491-1510.

Sorheim, H.-R., 2004. Klimateks engasjement innen Gasskraft med $\mathrm{CO}_{2}$-håndtering. Presentation for OED.

Statistics Norway, 2007. Natural Resources and the Environment 2006. Kongsvinger, Oslo. 
Sundkvist, S.G., Eklund, H., 2005. AZEP_-an EC funded project for development of a CCGT power plant without $\mathrm{CO}_{2}$ emissions. In: Fourth Nordic Minisymposium on $\mathrm{CO}_{2}$ Capture and Storage. Espoo, Finland.

Sundset, T., 2003. CO2-From problem to business opportunity. In: Third Nordic Minisymposium on $\mathrm{CO}_{2}$ Capture and Storage. Trondheim, Norway.

Suurs, R.A.A., Hekkert, M.P., 2008. Cumulative Causation in the Formation of Technological Innovation System: The Case of Biofuels in The Netherlands. Working Paper Series 08.04. Innovation Studies, Utrecht.

Thomas, D.C., Benson, S., 2005. Carbon Dioxide Capture for Storage in Deep Geologic Formations-Results from the $\mathrm{CO}_{2}$ Capture Project. Elsevier Science, London.

Tjernshaugen, A., 2006. Political commitment to $\mathrm{CO}_{2}$ capture and storage: evidence from government RD\&D budgets. Mitigation and Adaptation Strategies for Global Change 13 (1), 1-21.

Tjernshaugen, A., 2007. Gasskraft. Tjue års klimakamp. Pax forlag, Oslo.

Tjernshaugen, A., Lee, H., 2004. Shaming and Framing: Norwegian Nongovernmental Organizations in the Climate Change Negotiations. CICERO Working Paper 2004:09. Center for International Climate and Environmental Research-Oslo (CICERO), Oslo.
Torp, T.A., Gale, J., 2004. Demonstrating storage of $\mathrm{CO}_{2}$ in geological reservoirs: the Sleipner and SACS projects. Energy 29 (9-10), 1361-1369.

Torvanger, A., Rypdal, K., Tjernshaugen, A., 2007. Carbon capture and storage projects under the climate policy regime: the case of Halten $\mathrm{CO}_{2}$. CICERO Report 2007:09. Center for International Climate and Environmental ResearchOslo (CICERO), Oslo.

Trømborg, E., Bolkesjø, T.F., Solberga, B., 2007. Impacts of policy means for increased use of forest-based bioenergy in Norway-a spatial partial equilibrium analysis. Energy Policy 35 (12), 5980-5990.

Turkenburg, W.C., Blok, K., Hendriks, C.A., Steinberg, M., 1992. Proceedings of the First International Conference on Carbon Dioxide Removal. Pergamon Press Oxford, Amsterdam.

Ursin, T.P., Halvorsen, P.T., 2001. $\mathrm{HiO}_{x^{-}}$emission free gas power: a technology developed by Aker Maritime. In: Second Nordic Minisymposium on Carbon Dioxide Capture and Storage, Göteborg, Sweden.

van Alphen, K., Hekkert, M.P., van Sark, W.G.J.H.M., 2008. Renewable energy technologies in the Maldives-realizing the potential. Renewable and Sustainable Energy Reviews 12 (1), 162-180. 